\title{
THE RELATIONSHIP BETWEEN ACCOUNTING INDICATORS AND MARKET VALUE OF RUSSIAN COMPANIES WITH DIFFERENT GROWTH POTENTIAL
}

\author{
E.A. VOROBEVA, E. D. NIKULIN \\ Graduate School of Management, St. Petersburg University, Russia
}

\begin{abstract}
The paper investigates relationship between accounting and market indicators of Russian companies. The goal of the paper is to test the hypothesis that the power of companies' book value and earnings in explaining market value varies across Russian firms with different growth potential. Empirical study was carried out on the basis of 41 Russian traded companies that provided financial reports in accordance with international financial reporting standards (IFRS) for 2007-2013. These companies were divided into three groups using priceto-earnings indicator: with high, medium and low growth potential. The linear regression model based on the Ohlson's theoretical model was tested both on the whole sample of companies and on each subsample, the latter constituting a piece-wise linear function (growthbased model, GBM). The results of the tests show that GBM shows better accuracy in predicting companies' market capitalization than basic linear model. This result contributes to the stream of literature on non-linear equity valuation and provides insights for valuing Russian companies.
\end{abstract}

Keywords: market capitalization, book value, earnings, valuation, growth potential.

JEL: G30, G32.

The problem of companies' valuation is receiving nowadays an increasing amount of attention among academics as well as business practitioners. A company's value can be defined in two ways according to different aspects of a firm's presence on the market [Bukhvalov, Volkov, 2005]. Firstly, a company is present on the real market where its purchases, manufacturing and sales operations take place. These operations are reflected in corporate accounting system and have an impact on a firm's accounting reports. Based on these accounting reports, a firm can assess the prospects of its future financial position and results, which leads to the fundamental valuation of the company.

Postal Address: 3 Volkhovskiy per., Graduate School of Management, St. Petersburg University, St. Petersburg, 199004, Russian Federation.

(c) E.A. Vorobeva, E.D. Nikulin, 2018

https://doi.org/10.21638/spbu18.2018.405 
The model that is traditionally used to assess a company's fundamental value was proposed by J.Ohlson [Ohlson, 1995; Feltham, Ohlson, 1995]. Secondly, a company itself can be considered as an object of trade on the capital market where the rights of ownership and control are redistributed. Such an approach leads to another corporate value indicator - market value or capitalization.

Market indicators of a company are considered to be dependent on its accounting indicators [see, e.g., Barth, Beaver, Landsman, 2001; Holthausen, Watts, 2001]. The general idea is that corporate accounting reports are the main means of communication between a company and its investors. Consequently, based on accounting reports, investors can formulate their vision of a company's prospects as well as assess its risks [El-Gazzar, Finn, Tang, 2009].

Over the last decades a lot of studies have considered the nature of relationship between fundamental value of a company's equity (or separate accounting indicators of a company) and its market value (e.g., [Dechow, Hutton, Sloan, 1999; Myers, 1999; Morel, 2003; Gregory, Saleh, Tucker, 2005]). In doing so, the researchers tried to identify the accounting-based valuation model with the most explanatory power (e.g., [Ashbaugh, Olsson, 2002]). To put it differently, these studies emphasized the issue of value relevance of accounting information [Barth, Beaver, Landsman, 2001; Holthausen, Watts, 2001; Ciftci, Darrough, Mashruwala, 2014].

It should be noted that the majority of studies on fundamental valuation were conducted on the basis of data from developed markets, whereas emerging markets have received significantly less attention in this regard. The first paper to study the relationship between accounting and market indicators of Russian companies was [Bukhvalov, Volkov, 2005]. The authors came to a preliminary conclusion that the book value of equity as well as residual income can predict the market capitalization of companies on the Russian market. [Volkov, Berezinets, 2006] analyzed the comparative explanatory power of different valuation models on the Russian market. [Bukhvalov, Akulaeva, 2014] presented a modification of the Ohlson model and recommended its use as an instrument to assess the strategic value of the company (in terms of [Grant, 2010]). The impact of M\&A deals on the fundamental value of companies from BRIC countries is studied in [Rogova, Luzina, 2015]. The authors reveal that M\&A deals positively influence the fundamental value per share for acquirers. The wide range of issues concerning valuation of Russian companies is covered in [Bukhvalov, 2012].

The goal of the current paper is to test the hypothesis that the relationship between book value, earnings and market capitalization of Russian companies is not homogenous among different types of firms. The corresponding result has been obtained in many previous research papers [e.g. Burgstahler, Dichev, 1997; Collins, Pincus, Xie, 1999; Sohn, 2012; Herath et al., 2015]. They show that the power of companies' earnings and book value in explaining market capitalization differs significantly between companies with different financial position and economic prospects. Precisely, book value is shown to be more significant in explaining market value for companies with low efficiency / low growth potential, while earnings are more important in explaining market value for companies with high efficiency / high growth potential. Given that these results have been achieved on developed markets data, there was a strong motivation to investigate the same relationship on the emerging market of Russia. We use the growth-based model (GBM) that presents the corresponding relationship in the shape of piece-wise linear function, with each line segment referring to companies with different growth potential. This is the first time

RMJ 16 (4): 563-576 (2018) 
this model is tested on the sample of Russian firms.

The paper is organized as follows. Section 1 discusses the existing approaches to modelling the relationship between accounting and market indicators of a company. Section 2 provides research methodology. Section 3 presents the research sample used as well as descriptive statistics of data. Section 4 contains description of empirical results and their discussion. Section 5 concludes and provides directions for future research.

\section{The relationship between accounting and market indicators of a company: non-linearity and dependence from companies' growth potential}

The traditional approach to fundamental valuation of a company is generally based on the discounted dividends model. This model relies on the assumption that the value of a company depends in the first place on the discounted stream of its future dividends. This approach did not show the direct link between accounting data and a firm's value [Bernard, 1995]. In 1995 Ohlson proposed a model of companies' valuation that, under certain assumptions, mitigated this deficiency by stating the relationship between a company's financial statements indicators and its value without direct consideration of dividend forecasts [Ohlson, 1995; Feltham, Ohlson, 1995]. Within this model a company's fundamental value is a linear function of its book value of equity and a stream of discounted abnormal earnings that a company is expected to generate in the future. In other words, this model implies that the future abnormal earnings (which can be regarded as a proxy of a company's prospects) causes the fundamental value of equity to deviate from its book value on either the positive or negative side.
Around the end of the 1990s the first papers devoted to the empirical testing of the Ohlson model appeared (see, e.g., [Dechow, Hutton, Sloan, 1999; Myers, 1999; Morel, 2003]). In these papers several assumptions of the model were tested using statistical methods on large samples of companies' data. One stream of research papers indicates that linear functions are not the best way to approximate the impact of earnings and book value on equity value of a company. For example, the paper [Burgstahler, Dichev, 1997] reveals that equity value of a company is, indeed, a function of both earnings and book value, however the functional relationship is convex. Using a large sample of Compustat companies from 1976 to 1994 , the authors show that the coefficient on earnings increases when the ratio of earnings to book value goes up, while the coefficient on book value at the same time decreases. The study [Collins, Pincus, Xie, 1999] additionally shows that book value of equity plays an important role in priceearnings relationship: the omission of this variable creates negative bias in the coefficient on earnings for loss firms and positive bias in this coefficient for profit firms. This study also reports that the overall effect of earnings on market value is not the same across the sample considered: the coefficient on earnings is significantly larger for profit firms, than for loss firms.

The results obtained in [Burgstahler, Dichev, 1997; Collins, Pincus, Xie, 1999] explicitly state that the relationship between accounting and market indicators is not homogenous across firms. Precisely, the nature and power of this relationship depends on companies' financial position and results as well as their prospects for development. This finding is also reflected in [Zhang, 2000] who elaborates a valuation model that considers the following options for a company: a firm may prefer to expand its business operations when corporate activities are profitable (expansion option) or to close them 
down when corporate activities are unprofitable (abandonment option). Hence, the model considers the non-linear nature of the relationship between equity value, book value and earnings. What is more, the impact of earnings and book value on equity value is expected not to be the same depending on companies' growth potential. G. Zhang stipulates that given book value, there is a positive relationship between equity value and earnings for all companies. At the same time, the model expects book value to be more powerful in explaining equity value than earnings for low-efficiency firms, while the opposite result is expected for steadystate firms.

These findings can be explained economically. Book value of equity, according to accounting rules, represents the historical value of the resources that a company possesses. The efficiency of usage of these resources is generally measured by a company's earnings. Thus, it seems logical that net income is considered to be of greater importance for the determination of successful firms' value than balance sheet indicators. Alternatively, the book value of equity is more important for determination of value of the companies which resources are more likely to be used more efficiently in the alternative way compared to their current employment, i. e. for low-efficiency or financially distressed companies.

In [Sohn, 2012] the Zhang's model is empirically tested on the sample of all firms listed on the NYSE, AMEX and NASDAQ with available data for 1976-2006. The main findings are consistent with Zhang's model predictions. They reveal that firms with a large expansion (abandonment) option value experience better (worse) financial performance than those with a small options' value.

There were attempts to explicitly incorporate a real options component into the Ohlson model. According to the model provided in [Ashton, Cooke, Tippett, 2003], a company's equity value consists of two components: recursion value of equity (present value of future cash flows) and adaptation value (value of real options). [Ataullah, Higson, Tippett, 2006] use a sample of UK firms in order to empirically assess the extent to which real (adaptation) option contribute to the value of equity. [Ataullah, Rhys, Tippett, 2009] use the approach by [Ashton, Cooke, Tippett, 2003] in order to assess forms and magnitude of bias that are caused by using a linear model specification instead of a non-linear one. Their results show that this bias is especially pronounced for loss-making companies. The paper [Herath et al., 2015] proposes a non-linear equity valuation model that explicitly incorporates growth and adaptation options available to companies. The model is empirically tested on the sample of 226165 firm-year observations for 57 year period (19502006). The results confirm the existence of a non-linear relationship between equity value and accounting indicators. Additionally, book value is revealed as being more important in explaining equity value for low-efficiency companies, while earnings are more important in explaining equity value for high-efficiency companies.

\section{Research methodology}

The research was carried out in several stages. At the first stage, the relationship between accounting and market indicators was carried out for the whole sample of companies. The relationship between firms' market capitalization, book value of equity and net income was tested via regression model provided in [Collins, Pincus, Xie, 1999], that had been derived directly from the Ohlson's theoretical model [Ohlson, 1995]. We made two major adjustments to the model by [Collins, Pincus, Xie, 1999]. Firstly, in our paper this model was tested with zero intercept (constant term), implying that there is no economic sense in non-zero market

RMJ 16 (4): 563-576 (2018) 
value of a firm which is characterized by zero earnings and book value [Bukhvalov, Akulaeva, 2014]. Secondly, all the indicators were taken in absolute, not per share, numbers [Bukhvalov, Volkov, 2005]. As a result, the model specification is as follows:

$$
M V_{j}=\beta_{1} N I_{j}+\beta_{2} B V_{j-1}+\varepsilon_{j},
$$

where $M V_{j}$ is the company's market capitalization for the year; $N I_{j}$ is the company's net income for the year; $B V_{j-1}$ is the company's book value at the beginning of the year; $\varepsilon_{j}$ is an error term.

At the second stage, the GBM was designed to assess the influence of the same independent variables on market capitalization for the firms with different growth potential. The growth potential of each company was measured using price-to-earnings $(P / E)$ indicator [Siegel, 1998; 2013; Herath et al., 2015]. According to [Siegel, 1998], stocks that exhibit high price-to-earnings ratios are called growth stocks, because high $P / E$ ratio can be associated with expectations of future earnings growth. This is reasonable because overvaluation of company's current activities by the market can be mostly due to high expectations of investors for future cash flows. The $P / E$ ratio was computed in accordance with the following formula:

$$
\frac{P}{E}=\frac{M V_{j}}{N I_{j}} .
$$

Hence, the sample was divided into three subsamples with equal number of observations by price-to-earnings $(P / E)$ ratio: "low", "medium" and "high". Observations with highest $P / E$ ratio ( $1^{\text {st }}$ third of the sample) were allocated to the "high" group which means that these companies are perceived by investors as having high growth potential due to company's overvaluation compared to their book value. Observations with moderate $P / E$ ratio ( $2^{\text {nd }}$ third of the sample) were allocated to the "medium" group meaning that these companies are evaluated in conformity with their book value and no significant growth is expected. The "low" group ( $3^{\text {rd }}$ third of the sample) was constructed from companies with low $P / E$ ratio and companies for which the multiple is not applicable, i.e. firms with negative net income. These companies are unlikely to grow in the foreseeable future and mostly are on the verge of bankruptcy or reorganization.

To introduce a GBM, for each sub-sample the following linear OLS regressions were built:

$$
\begin{aligned}
& M V_{l j}=\beta_{1 l} N I_{l j}+\beta_{2 l} B V_{l j}+\varepsilon_{l j}, \\
& M V_{m j}=\beta_{1 m} N I_{m j}+\beta_{2 m} B V_{m j}+\varepsilon_{m j}, \\
& M V_{h j}=\beta_{1 h} N I_{h j}+\beta_{2 h} B V_{h j}+\varepsilon_{h j},
\end{aligned}
$$

where subscripts $l, m, h$ indicate low, medium and high growth potential groups respectively.

Estimated coefficients of models (3)-(5) were tested for difference using a series of Chow tests [Chow, 1960]. Firstly, the statistical significance of the difference in the regression coefficients of (3)-(5) was tested individually for each pair of coefficients. The null hypotheses assumed the equality of the coefficients. Secondly, the joint hypotheses were tested for the difference of the whole models (3)-(5) compared to each other. The comparison of the models for different groups of firms was performed with the null hypotheses that both coefficients for net income and for book value are equal between the models (3)-(5). These joint tests provide an opportunity to analyze the difference in the explanatory power of independent variables for the three subsamples. Thirdly, the GBM regression coefficients were tested for the statistically significant difference from the estimates of the basic model. In doing so, we tested the adequacy of the piece-wise linear functional form that 
was selected to approximate the relationship between a company's accounting and market indicators.

At the third stage, additional analyses were conducted in order to compare the explanatory power of the basic model and GBM. These analyses were based on the comparison of predicted market values according to (1) and (3)-(5) with actual capitalizations.

The following methods were used:

\section{Samples' mean and variance equality tests}

Test for means' equality has the following shape:

$$
\begin{aligned}
& \mathrm{H}_{0}: \bar{x}_{1}=\bar{x}_{2}\left(\mathrm{H}_{\mathrm{a}}: \bar{x}_{1} \neq \bar{x}_{2}\right), \\
& Z^{*}=\frac{\bar{x}_{1}-\bar{x}_{2}}{\sqrt{\frac{n_{1} \cdot S_{1}^{2}+n_{2} \cdot S_{2}^{2}}{n_{1}+n_{2}-2} \cdot\left(\frac{1}{n_{1}}+\frac{1}{n_{2}}\right)}},
\end{aligned}
$$

where $\bar{x}_{i}$ is sample mean, $n_{i}$ is sample size, $S_{i}^{2}$ stands for sample variance.

Test for variance equality can be presented as follows:

$$
\begin{aligned}
& \mathrm{H}_{0}: S_{1}^{2}=S_{2}^{2}\left(\mathrm{H}_{\mathrm{a}}: S_{1}^{2} \neq S_{2}^{2}\right), \\
& F=\frac{S_{1}^{2}}{S_{2}^{2}}
\end{aligned}
$$

where $S_{i}^{2}$ is sample variance.

\section{Mean absolute percentage error comparison}

Another approach was based on mean absolute percentage error (MAPE) that is computed according to the following formula:

$$
M A P E=\frac{100 \%}{n} \sum_{t=1}^{n}\left|\frac{A_{t}-F_{t}}{A_{t}}\right|,
$$

where $A_{t}$ is actual value, $F_{t}$ is estimated value.

The use of absolute values in (10) provides an opportunity to account for both overestimation and underestimation of the firm value as an error in the model. Additional advantage of this indicator is that the percentage estimation supports the independency of judgement from the size effect of the companies in the samples.

\section{Sample}

The initial sample was formed from Russian traded companies which provided consolidated financial reports according to international financial reporting standards (IFRS) for 2007-2013. Later years have not been considered to avoid the influence of economic sanctions that started in 2014. These sanctions increased the volatility of rouble exchange rate and thus complicated analysis performed on the data measured in Russian national currency. After initial sample was completed, companies from finance sector were excluded. What is more, we excluded observations (companies-years) for which at least one of the variables was missing. Finally, we arrived at a dataset with seven years of observations for 41 companies. The total amount of observations is 207.

The main sources of accounting data were SKRIN database (http://www.skrin.ru) and the official web sites of the companies. The sources of market data were online databases Investfunds (http://www.investfunds.ru) and Bloomberg Institute (http://www.bloomberg.com). They report market capitalization of the companies at any required date.

In case the company reported its financials in other currency than Russian roubles, the accounting data were recalculated into national currency using the exchange rate of Central Bank of Russia at the last day of the year.

The resulted sample was divided into three subsamples ("high", "medium" and "low") according to their $P / E$ ratio. The subsamples consisted of the equal number of observations: 69. The maximum value of $P / E$ in the "high" group was 57.4; in the "medium" group 11.8; and in the "low" group 4.95. 
Table 1

Descriptive statistics of the sample of data, mln RUR

\begin{tabular}{l|c|c|c|c|c}
\hline Sample/subsample & Variable & Mean & Standart deviation & Min & Max \\
\hline Overall sample & $M V$ & 93875 & 121884 & 508 & 561109 \\
\cline { 2 - 7 } & $N I$ & 6466 & 10409 & -24030 & 43485 \\
\cline { 2 - 7 } & $B V$ & 71109 & 93861 & -9636 & 537915 \\
\hline \multirow{4}{*}{ "Low" subsample } & $l M V$ & 48398 & 76213 & 508 & 523854 \\
\cline { 2 - 7 } & $l N I$ & 3036 & 11355 & -24030 & 31760 \\
\cline { 2 - 7 } subsample & $l B V$ & 62800 & 84863 & 3956 & 390657 \\
\hline \multirow{4}{*}{ "High" subsample } & $m M V$ & 84303 & 96279 & 2861 & 376375 \\
\cline { 2 - 7 } & $m N I$ & 10041 & 11142 & 387 & 43485 \\
\cline { 2 - 7 } & $m B V$ & 79254 & 104201 & 2182 & 537915 \\
\cline { 2 - 7 } & $h N I$ & 6321 & 157034 & 6202 & 561109 \\
\cline { 2 - 7 } & $h B V$ & 71272 & 92151 & -9636 & 405800 \\
\hline
\end{tabular}

Table 2

Regression models estimation

\begin{tabular}{l|c|c|c|c}
\hline \multirow{2}{*}{ Sample/subsample } & \multicolumn{2}{|c|}{ Coefficient } & \multirow{2}{*}{$\boldsymbol{R}_{\text {adj }}^{2}$} & \multirow{2}{*}{-test (significance of the model) } \\
\cline { 2 - 3 } & $\boldsymbol{N}$ & $\boldsymbol{B} \boldsymbol{V}$ & & \\
\hline Overall & $4.72^{* * *}$ & $0.72^{* * *}$ & 0.65 & $195.58^{* * *}$ \\
\hline "Low" & 0.25 & $0.68^{* * *}$ & 0.62 & $57.63^{* * *}$ \\
\hline "Medium" & $7.81^{* * *}$ & $0.09^{* *}$ & 0.97 & $1319.10^{* * *}$ \\
\hline
\end{tabular}

Not e: ${ }^{*}-$ significant at $10 \% ;{ }^{* *}-$ significant at $5 \% ;{ }^{* * *}-$ significant at $1 \%$.

Table 1 presents descriptive statistics for the overall sample as well as for the subsamples of data used.

According to Table 1, the largest mean capitalization corresponds to the companies of "high" subsample. This is in line with the fact that these companies have the largest $P / E$ ratios. The smallest mean value of market capitalization belongs to the companies of "low" subsample (subsample with the lowest $P / E$ ratios). Some of companies of this subsample also have negative net income.

\section{Results and discussion}

Table 2 provides OLS estimates of coefficients of the regression models that were tested both for the overall sample and subsamples.

Table 2 shows that the models that were tested both on the whole sample of data and on subsamples are statistically significant at $1 \%$ level. All the variables (except for the "low" subsample) are also statistically significant and have direct relationship to market capitalization as expected. For the "low" group net income variable is not significant in the model, meaning that net income does not affect market value for the firms, which barely have growth potential. As for the "medium" group, the results are foreseeable: both net income and book value of equity play a significant role in explaining the firms' market value. However, judging by the value of the coefficient, net 
Table 3

Chow test individual results

\begin{tabular}{l|c|c}
\hline Null hypothesis & $\boldsymbol{F}$-statistics & Conclusion about null hypothesis \\
\hline$b_{1 l}-b_{1 m}=0$ & $63.47^{* * *}$ & Rejected \\
\hline$b_{1 m}-b_{1 h}=0$ & $49.44^{* * *}$ & Rejected \\
\hline$b_{1 l}-b_{1 h}=0$ & $192.4^{* * *}$ & Rejected \\
\hline$b_{2 l}-b_{2 m}=0$ & $30.59^{* * *}$ & Rejected \\
\hline$b_{2 m}-b_{2 h}=0$ & $10.55^{* * *}$ & Rejected \\
\hline$b_{2 l}-b_{2 h}=0$ & $3.77^{* *}$ & Rejected \\
\hline
\end{tabular}

Not e: ${ }^{*}$ - significant at $10 \%$; ${ }^{* *}$ - significant at $5 \%$; ${ }^{* * *}$ - significant at $1 \%$.

Table 4

Chow tests for joint hypotheses for difference between groups

\begin{tabular}{c|c|c|c}
\hline \multicolumn{2}{c|}{ Null hypothesis } & F-statistics & Conclusion about null hypothesis \\
\hline \multirow{2}{*}{$\& \mathrm{M}$} & $b_{1 l}-b_{1 m}=0$ & $34.28^{* * *}$ & Rejected \\
\cline { 2 - 2 } & $b_{2 l}-b_{2 m}=0$ & & \\
\hline \multirow{2}{*}{$\& \mathrm{M}$} & $b_{1 m}-b_{1 h}=0$ & $98.83^{* * *}$ & Rejected \\
\cline { 2 - 2 } & $b_{2 m}-b_{2 h}=0$ & & \\
\hline $\mathrm{L} \& \mathrm{H}$ & $b_{1 l}-b_{1 h}=0$ & \multirow{2}{*}{$107.44^{* * *}$} & Rejected \\
\cline { 2 - 2 } & $b_{2 l}-b_{2 h}=0$ & & \\
\hline
\end{tabular}

Not e: ${ }^{*}$ - significant at $10 \%{ }^{* *}$ - significant at $5 \%$; ** - significant at $1 \%$.

income has more explanatory power than book value for this group of companies. In the "high" group the results are opposite to the ones obtained in the low group. Both variables are statistically significant at $1 \%$ significance level. However, the role of book value is rather small in explaining the capitalization of high growing firms.

In order to test whether GBM better fits the empirical data, it was important to conduct a statistical test for the difference between these regressions' coefficients.

First of all, the groups' coefficients have been compared by pairs. Table 3 summarizes the results of the tests.

Each pair of coefficients individually is statistically different at $1 \%$ significance level except for the pair $b_{2 l}-b_{2 h}$, which is supposed not to be equal only at $5 \%$ level. That means the difference in explanatory power of book value on market value between low and high growth firms is smaller compared to the other pairs of subsamples.

It was also reasonable to compare the models as a whole between groups, i.e. conduct a joint hypotheses testing that the coefficients for net income and book value together vary across groups. The corresponding results are presented in Table 4.

Table 4 shows that all three models are statistically different, because low $p$-values allow us to reject the null hypothesis that both pairs of coefficients in regressions are equal. Together with individual tests, this result means that the estimated equations for three groups of companies are statistically different.

After that, we tested the difference of the models built on subsamples and on overall sample. Table 5 summarizes the results 
Table 5

Chow tests for groups' regression coefficients difference from regression coefficients for the whole sample

\begin{tabular}{c|c|c}
\hline Null hypothesis & F-statistics & Conclusion about null hypothesis \\
\hline$b_{1 l}=b_{1}$ & $56.64^{* * *}$ & Rejected \\
\hline$b_{2 l}=b_{2}$ & 0.38 & Not rejected \\
\hline$b_{1 m}=b_{1}$ & $17.43^{* * *}$ & Rejected \\
\hline$b_{2 m}=b_{2}$ & $56.04^{* * *}$ & Rejected \\
\hline$b_{1 h}=b_{1}$ & $136.21^{* * *}$ & Rejected \\
\hline$b_{2 h}=b_{2}$ & $8.75^{* * *}$ & Rejected \\
\hline
\end{tabular}

Not e: ${ }^{*}$ - significant at $10 \% ;{ }^{* *}-$ significant at $5 \% ; * * *$ significant at $1 \%$.

Table 6

Descriptive statistics of observed and estimated market capitalization

\begin{tabular}{l|c|c|c}
\hline \multirow{2}{*}{ Indicator } & \multirow{2}{*}{ Observed capitalization, mln RUR } & \multicolumn{2}{|c}{ Estimated values, mln RUR } \\
\cline { 3 - 4 } & & Basic model & GBM \\
\hline Mean & 93875 & 81940 & 89513 \\
\hline Standard deviation & 121884 & 93866 & 111629 \\
\hline
\end{tabular}

of the Chow tests for the difference between each subsample regression coefficients and overall sample regression coefficients.

The Chow tests show that the regression coefficients of "medium" and "high" groups on net income and book value of equity variables are statistically different from coefficients of the regression for the whole sample. However, for the "low" group the coefficient on net income is the only one that significantly differs from the overall regression coefficients. The hypothesis that $b_{21}$ coefficient on book value in the "low" group equals to the coefficient on the same variable in the whole sample regression was not rejected.

After a series of Chow tests revealed that the estimation of regression coefficients on the subsamples of companies with different economic growth was appropriate, we could compare the explanatory power of GBM and that of the basic model. First of all, we compared $R^{2}$. The result shows that the explanatory power of GBM is higher than the basic one, since average adjusted $R^{2}$ of this model is 0.82 compared to 0.65 of the basic regression.

It was also possible to test the accuracy of market value estimation by both models by comparing the following sets of data: actual capitalizations to those estimated with regression model built on the whole sample; and actual capitalizations to those estimated with GBM. Table 6 summarizes the statistics of each analyzed sample.

As shown in Table 6, GBM delivers estimated values that have mean and standard deviation closer to the actual data than those predicted by the basic model. Table 7 presents the results of means and variance equality tests between actual capitalization and GBM predicted values and between actual capitalization and the basic model predicted values.

As Table 7 shows, it is not possible to the reject the hypothesis about the equality of means between actual capitalization and that delivered via the basic model. However, the variance of capitalization predicted by this model is statistically lower than 
Table 7

The results of mean and variance equality tests between actual capitalization and predicted values

\begin{tabular}{l|c|c|c|c}
\hline \multirow{2}{*}{ Indicator } & \multicolumn{2}{c|}{ Actual vs Basic model } & \multicolumn{2}{c}{ Actual vs GBM } \\
\cline { 2 - 5 } & Mean equality & Variance equality & Mean equality & Variance equality \\
\hline Null hypothesis & $\bar{x}_{1} \bar{x}_{2}$ & $S_{1}^{2}=S_{2}^{2}$ & $\bar{x}_{1}=\bar{x}_{3}$ & $S_{1}^{2}=S_{3}^{2}$ \\
\hline$Z^{*}$ & 1.11 & 1.69 & 0.38 & 1.19 \\
\hline Acceptance area & $(-1.97 ; 1.97)$ & $(-\infty ; 1.26)$ & $(-1.97 ; 1.97)$ & $(-\infty ; 1.26)$ \\
\hline Conclusion about null hypothesis & Not rejected & Rejected & Not rejected & Not rejected \\
\hline
\end{tabular}

Table 8

Mean absolute percentage errors for the basic model and for growth-based model

\begin{tabular}{l|c|c}
\hline \multirow{2}{*}{ Subsample } & \multicolumn{2}{|c}{ Mean absolute percentage error, \% } \\
\cline { 2 - 3 } & Basic model & GBM \\
\hline "Low" & 276 & 154 \\
\hline "Medium" & 63 & 28 \\
\hline "High" & 56 & 43 \\
\hline Average & 132 & 75 \\
\hline
\end{tabular}

the variance of the actual capitalization. At the same time, according to the results, GBM gives more precise estimation of market value, since it is not possible to reject hypotheses about equality of means and variances between predicted values of market capitalization delivered via GBM and actual capitalization.

Another test for model accuracy was performed via MAPE indicator computed according to (10) for each subsample. The results of MAPEs calculation are presented in Table 8.

As shown in Table 8, both average MAPEs and MAPEs on individual subsamples for GBM are lower than those for the basic model. The largest MAPEs for both models are achieved on the subsample of the low growth companies.

All the above analyses generally provide evidence that the GBM which accounts for the groups' differences in economic growth outperforms the basic model which treats all the companies equally. Based on the results of our research, the following inference can be made for the companies with different economic potential.

Firms with low growth potential

As has been predicted, the main explanatory factor on market capitalization for the firms with low growth potential is book value of equity. Companies that have low $P / E$ ratio or negative earnings, according to investors, provide small opportunities for growth, that is why the contribution of earnings into market value of these companies is small. The market usually evaluates these companies mostly on the basis of book value of equity that gives a proxy of their liquidation value.

\section{Firms with medium growth potential}

For the firms with medium growth potential both net income and book value indicators contribute to market value of these companies, although book value of equity has lower explanatory power on the capitalization than net income. This is consistent with G. Zhang's prediction that for steady- 
state firms the main explanatory variable are earnings, while book value provides little explanatory power [Zhang, 2000].

\section{Firms with high growth potential}

The regression analysis has shown that both net income and book value of equity are significant in explaining companies' market capitalization with net income having more explanatory power. This result supports the idea that the growing firms should be evaluated mainly by the future or expected earnings they can generate, not by their liquidation value. On the other hand, the significant explanatory power of book value of equity may be caused by the fact that this variable should be interpreted differently for this group of companies. According to [Burgstahler, Dichev, 1997] assets are used more efficiently in the firms with high growth potential compared to the firms with low growth potential. Therefore, the book value for the high growth group should be treated as the base for future profit generation, not as a proxy for liquidation value as in the case of the low growth group.

\section{Conclusion}

The current study was devoted to the relationship between book value, earnings and market capitalization of Russian companies. We followed the propositions of [Burgstahler, Dichev, 1997; Collins, Pincus, Xie, 1999; Zhang, 2000], according to which the relationship between accounting and market indicators of a company is non-linear and, what is more, depends on a firm's financial position and prospects for development.

The sample for empirical study consisted of 41 companies that prepared their financial reporting according to IFRS for 20072013. They were divided into three subsamples ("low", "medium" and "high") according to $P / E$ indicator. The group with the highest $P / E$ values was labeled as having high economic growth potential; the group that had the lowest $P / E$ or negative earnings was considered as having low economic growth potential; the group with medium $P / E$ values was supposed to have medium economic growth potential.

Two kinds of regression analysis were performed for this sample of companies. The first approach was to test the linear regression model that links market capitalization to book value of equity and net income on the whole sample. This approach is based on the Ohlson's valuation model. The second approach was to test the model with the same variables on each subsample ("high", "medium" and "low") separately. To put it differently, the latter approach uses piece-wise linear relationship and is called GBM.

A series of tests was performed in order to compare these two approaches. Firstly, the Chow tests showed that GBM is more appropriate than a single linear function on the sample of data considered. Additionally, it was shown that GBM delivers estimates of market capitalization that are closer to actual data than those obtained via a single linear model. In other words, it was shown that on the sample of data considered the model, which accounts for difference in relationship between capitalization, book value and earnings for firms with different growth potential has higher explanatory power than the basic linear model that makes no distinction between companies.

Additional insights were obtained for separate indicators on the ability to explain market capitalization. The explanatory power of net income increases with the growth potential of a company, while the low growing firms' market value is not driven by net income at all. The book value of equity, on the other hand, has strong relationship with the market capitalization for low growing firms and for high growing firms. The corresponding relationship for firms with medium growth potential is weaker.

The main limitation of our study is a relatively small sample size that is generally 
restricted, first, by the number of actively traded Russian companies and, second, by the period of observation that can hardly be enlarged. After 2014 the macroeconomic conditions in Russia have changed significantly and, hence, the analysis of relationship between market and fundamental value of Russian companies became more complicated. The main issue concerns increased rouble volatility that undoubtedly influences both accounting and market indicators. As a result, it becomes unclear what currency should be used in calculations and how to single out the effect caused by sanctions and subsequent changes of currency exchange rate.

We believe that the results of current study have practical importance, since they provide insights on valuing Russian companies. The main conclusion is that valuation models should differ according to economic characteristics of companies, precisely, their

\section{REFERENCES}

Ashbaugh H., Olsson P. 2002. An exploratory study of the valuation properties of crosslisted firms' IAS and U.S. GAAP earnings and book values. Accounting Review 77 (1): 107-126.

Ashton D., Cooke T., Tippett M. 2003. An aggregation theorem for the valuation of equity under linear information dynamics. Journal of Business Finance and Accounting 30 (3-4): 413-440.

Ataullah A., Higson A., Tippett M. 2006. Real (adaptation) options and the valuation of equity: Some empirical evidence. Abacus $\mathbf{4 2}$ (2): $236-265$.

Ataullah A., Rhys H., Tippett M. 2009. Nonlinear equity valuation. Accounting and Business Research 39 (1): 57-73.

Barth M.E., Beaver W.H., Landsman W.R. 2001. The relevance of the value relevance literature for financial accounting standard setting: Another view. Journal of Accounting and Economics 31 (1-3): 77-104. financial position and growth perspectives. By identifying a company's growth potential, it becomes possible to predict what accounting indicator (book value or earnings) will explain the major part of its market capitalization in recent future. On the other hand, ignoring the difference in valuation of companies with different growth potential may lead to misevaluation of the company and errors in decision-making.

A potential direction for future research could be additional development of nonlinear equity valuation models. As the paper [Ataullah, Rhys, Tippett, 2009] points out, empirical research on the determinants of market value of equity is still predominantly based on linear models that do not account for real options available to companies and, hence, produce biased results. The elaboration of advanced option-based models would mitigate this bias and make the valuation results more accurate.

Bernard V. 1995. The Feltham-Ohlson framework: Implications for empiricists. Contemporary Accounting Research 11 (2): 733-747.

Bukhvalov A. V. (ed.). 2012. Corporate Governance: Topics in Practice and Valuation of Russian Companies. GSOM Publisihng House: St. Petersburg. (In Russian)

Bukhvalov A. V., Akulaeva E.A. 2014. Empirical fundamental value of Russian companies: In search for strategic value. Russian Management Journal 14 (2): 3-12. [In Russian]

Bukhvalov A. V., Volkov D.L. 2005. The research of relationship between fundamental value indicators and market capitalization of Russian companies. Vestnik of Saint Petersburg University. Management 4 (1): 26-43. (In Russian)

Burgstahler D., Dichev I. 1997. Earnings, adaptation value and equity value. Accounting Review 72 (2), 187-215. 
Chow G.C. 1960. Tests of equality between sets of coefficients in two linear regressions. Econometrica 28 (3): 591-605.

Ciftci M., Darrough M, Mashruwala R. 2014. Value relevance of accounting information for intangible-intensive industries and the impact of scale: The US evidence. European Accounting Review 23 (2): 199-226.

Collins D., Pincus M., Xie H. 1999. Equity valuation and negative earnings: The role of book value of equity. Accounting Review 74 (1): 29-61.

Dechow P., Hutton A., Sloan R. 1999. An empirical assessment of the residual income valuation model. Journal of Account ing and Economics 26 (1-3): 1-34.

El-Gazzar S. M., Finn P. M., Tang C. 2009. The value relevance of earnings and nonearnings information in regulated and deregulated markets: The case of the airline industry. International Advances in Economic Research 15 (1): 88-101.

Feltham G., Ohlson J. 1995. Valuation and clean surplus accounting for operating and financial activities. Contemporary Accounting Research 11 (2): 689-731.

Grant R. 2010. Shareholder value maximization: Rehabilitating a 'dumb idea'. Competitive Strategy Newsletter 4 (1): 9-11.

Gregory A., Saleh W., Tucker J. 2005. A UK test of an inflation-adjusted Ohlson model. Journal of Business Finance and Accounting 32 (3-4): 535-548.

Herath H. S. B., Richardson A. W., Roubi R. R., Tippett M. 2015. Non-linear equity valuation: An empirical analysis. Abacus 51 (1): 86-115.

Holthausen R., Watts R. 2001. The relevance of the value-relevance literature for finan- cial accounting standard setting. Journal of Accounting and Economics 31 (1-3): 3-75.

Morel M. 2003. Endogenous parameter time series estimation of the Ohlson model: Linear and non-linear analysis. Journal of Business Finance and Accounting 30 (910): 1341-1362.

Myers J. 1999. Implementing residual income valuation with linear information dynamics Accounting Review 74 (1): 1-28.

Ohlson J. 1995. Earnings, book values, and dividends in security valuation. Contemporary Accounting Research 11 (2): 661687.

Rogova E., Luzina D. 2015. The effect of mergers and acquisitions on companies' fundamental values in emerging capital markets (the case of BRICS). E-Journal of Corporate Finance 35 (3): 27-50. (In Russian)

Siegel J. 1998. Stocks for the Long Run. The Definitive Guide to Financial Market Returns and Long-Term Investment Strategies. McGraw-Hill: N.Y.

Siegel J. 2013. Stocks for the Long Run. McGraw-Hill: N.Y.

Sohn B.C. 2012. Equity value, implied cost of equity and shareholders' real options. Accounting and Finance 52 (2): 519-541.

Volkov D. L., Berezinets I. V. 2006. Value-based management: The issue of accuracy of accounting-based valuation models. Vestnik of Saint Petersburg University. Management 5 (4): 3-32. (In Russian)

Zhang G. 2000. Accounting Information, capital investment decisions, and equity valuation: Theory and empirical implications. Journal of Accounting Research 38 (2): 271-295.

Initial Submission: December 1, 2018

Final Version Accepted: December 24, 2018

\section{Связь между учетныли показателяли и рыночной ценностью российских колпаний с различнылм потенциалол роста}

\section{E. A. Воробъева}

Выпускница программы магистратуры «Корпоративные финансы» Санкт-Петербургского государственного университета, Россия

E-mail: ekaterina.a.vorobeva@gmail.com 


\section{Е.Д. Никулин}

Доцент, Высшая школа менеджмента Санкт-Петербургского государственного университета, Россия

E-mail: nikulin@gsom.spbu.ru

В статье исследуется связь между бухгалтерскими и рыночными показателями российских компаний. Целью работы является проверка гипотезы о том, что объясняющая сила показателей балансовой стоимости и прибыли компаний для величины рыночной стоимости варьируется для российских компаний в зависимости от потенциала их роста. Эмпирическое исследование было проведено на данных по 41 торгуемой в России компании, предоставлявшей финансовую отчетность в соответствии с международными стандартами финансовой отчетности (МСФО) в 2007-2013 гг. Эти компании были разделены на три группы с использованием показателя $P / E$ : компании с высоким, средним и низким потенциалом роста. Основанная на теоретической модели Олсона модель линейной регрессии была протестирована как на всей выборке компаний, так и на каждой подвыборке, причем последняя представляет собой кусочно-линейную функцию (модель, основанная на росте - GBM). Результаты тестов демонстрируют, что GBM показывает лучшую точность в прогнозировании рыночной капитализации компаний, чем базовая линейная модель. Полученные результаты вносят вклад в массив исследований по проблематике нелинейной оценки капитала и развивают знания об оценке российских компаний.

Ключевые слова: рыночная капитализация, балансовая стоимость, прибыль, оценка, потенциал роста.

JEL: G30, G32.

For citation: Vorobeva E. A., Nikulin E.D. 2018. The relationship between accounting indicators and market value of Russian companies with different growth potential. Russian Management Journal 16 (4): 563-576. https://doi.org/10.21638/spbu18.2018.405

https://doi.org/10.21638/spbu18.2018.405

Статья поступила в редакиию 1 декабря 2018 г. Принята к публикации 24 декабря 2018 г. 